\title{
The Cost-estimation of Mechanical Pre-treatment Lines of Municipal Solid Waste in Latvia
}

\author{
Dace Āriņa ${ }^{1 *}$, Kaspars Kḷavenieks² ${ }^{2}$ Juris Burlakovs ${ }^{3}$ \\ ${ }^{1}$ Department of Environment and Water Management, LLU, Akademijas iela 19, Jelgava, LV-3001, Latvia \\ ${ }^{2}$ Institute of Energy Systems and Environment, RTU, Kalku iela 1, Riga, LV-1658, Latvia \\ ${ }^{3}$ Department of Environmental Science, LU, Raina bulv.19, Riga, LV-1586, Latvia
}

\begin{abstract}
Production of refuse derived fuel from municipal solid waste in future shall play a strategic role in an integrated waste management system. The amount of landfilled biodegradable materials thus will be diminished according to provisions of the 1999 Waste Landfill Directive. The aim of this article is to evaluate cost effectiveness based on cost evaluation of the different complication of the waste pre-treatment equipment complectation and based on regenerable waste quantities in Latvia. The comparison of cost estimates is done in 3 scenarios considering potential waste quantities in Latvia: Scenario I - planned annual waste quantity is $20 \mathrm{kT}$; Scenario II - $40 \mathrm{kT}$ and Scenario III - $160 \mathrm{kT}$. An increase in amount of waste and processing capacity means the decrease in costs of mechanical pre-treatment of 1 ton of waste. Thus, costs of mechanical sorting line under different scenarios with capacities of $10 \mathrm{t} \mathrm{h}^{-1}, 20 \mathrm{t} \mathrm{h}^{-1}$ and $80 \mathrm{t} \mathrm{h}^{-1}$ are EUR 32 per t, EUR 24 per $t$ and EUR 15 per $t$, respectively. Most feasible cost for a set of mechanical pre-treatment equipment for the capacity of $10 \mathrm{t} \mathrm{h}^{-1}$ is EUR 32 per $\mathrm{t}$ by using rotating drum screener with the following manual sorting. Mechanical pre-treatment equipment of unsorted municipal waste is economically nonbeneficial, when the use of fine (biologically degradable) fraction is not possible. As the sorting of biodegradable kitchen waste is not developed under the current waste management system in Latvia, the lines for mechanical pre-treatment of household waste would be better to install in landfills.
\end{abstract}

Key words: mechanical pre-treatment, municipal solid waste, capital costs, operation costs.

\section{Introduction}

The National Waste Management Plan for 20132020 has set relatively high implementation objectives for the separate collection of organic waste, recycling and landfill in concordance with the requirements under the European Union (EU) Directive 1999/31/EC on the landfill of waste and the Directive 2008/98/EC on waste (European Parliament, 2008). It stipulates that only $35 \%$ of the amount of biodegradable waste (BDW) landfilled in 1995 can be landfilled in 2020. A problem for the national waste management is created by the requirement under the Directive 2008/98/EC that until 2020 , as much as $50 \%$ of household waste must be recycled.

The European Commission's study (European Commission, 2012) on the implementation of waste management directives in the 27 EU member states indicated to the significant dependence of the Latvian waste management system on waste landfills, which, in its turn, has created a number of subsequent problems such as: a large quantity of landfilled waste; the reduction objectives for BDW landfilling have not been met, leading to a large percentage of BDW in the landfilled waste and a small amount of processed municipal solid waste. According to the Latvian
Environment, Geology and Meteorology Centre data, $77 \%$ of the 826 thousand t of municipal solid waste generated in 2010, and 58\% of the 983 thousand $t$ generated unsorted municipal solid waste in 2011 was landfilled.

Setting up sustainable landfills and creation of infrastructure conforming to environmental protection requirements are in the task list for Latvia upon joining the EU. In order to assure the fastest possible development of sustainable waste management, ten waste management regions (WMR) were defined for efficient planning of waste management and sustainable use of local resources and EU funds. Landfills of all WMRs are managed by inter-municipal companies, but the next step is to organise the waste management system which would assure both: the long and sustainable service of landfills and compliance with new requirements in the waste management. It must lead to prevention of waste, increasing of waste recycling and regeneration thus affecting volumes and type of landfilled waste.

Landfilling of untreated municipal solid waste is unable to meet the rising demands in the area of environmental protection. In 2010, the amount of emissions generated by the waste sector in Latvia

\footnotetext{
* Corresponding Author's email:

dace.arina@gmail.com
} 
reached $5.5 \%$ of the total greenhouse gas (GHG) emissions generated by the economic sectors (12 $098 \mathrm{Gg} \mathrm{CO}_{2}$ equivalent) (UNFCCC, 2012). The EU Directive 1999/31/EC on the landfill of waste stipulates that the pre-treatment of waste needs to be ensured in all the EU member states.

Regarding the waste management system in Latvia, a target has been set of decreasing emissions potentially causing the greenhouse effect from biodegradable waste in landfills. The National Waste Management Plan for 2013-2020 provided for the installation of mechanical biological treatment equipment in all waste management regions by the end of 2013 to divert waste to composting, incineration or other equipment where no waste sorting is established at source. The use of separated organic part as a fuel can be considered as one of the solutions to reduce the amount of the landfilled waste. Production of refuse derived fuel (RDF) from municipal solid waste in future shall play a strategic role in an integrated waste management system. Mechanical biological pretreatment (MBP) is considered an alternative to waste incineration (Ritzkowski, Heerenklage, \& Stegmann, 2006), although one of the products resulting from the MBP process is a fuel intended for burning. Therefore, mechanical biological pre-treatment of waste is widely used in Austria and Germany as of 2005 in order to decrease volumes of biologically degradable waste (Stegmann, 2005).

Mechanical biological treatment (MBT) is beneficial considering high cost of waste incineration and well developed system of collection of source sorted waste. Currently, there are no waste incineration plants in Latvia, but in the coming years options will be open for the refuse derived fuel (RDF) prepared from waste to be incinerated in neighbouring countries (Rimaityte, Denafas, Martuzevicius, \& Kavaliauskas, 2010; KUT, 2007). The RDF can be used as the high quality alternative fuel in cement production plant in Latvia.

Every municipality is organising management of waste itself according to binding rules of the municipality considering State and regional waste management plans. Introduction of sorted waste collection system is planned in each waste management region by 2013. According to requirements of EU directives and national laws, municipalities in cooperation with waste managers shall ensure that by January 1, 2015 each municipality provides all residents with sorted waste collection service, by collecting at least sorted glass, paper, metal and plastics.

Over the past 10 years, scientific research on alternative and renewable resources, including the use of waste for energy production has been developing rapidly worldwide. In Latvia, research on opportunities for unsorted municipal solid waste treatment, including refuse derived fuel generation, which would facilitate the national economic benefits, thereby ensuring preservation and further improvement of the environmental quality is insufficient. One of the few studies (Pubule, Kamenders, Valtere, \& Blumberga, 2014) has analysed seven biowaste management scenarios for Baltic countries by multi-criteria analysis, system dynamics modelling and a correlation-regression analysis. It is concluded there, that anaerobic digestion of separately collected biowaste would be the best solution for Latvia. Dāce et al. (Dāce, Bērziņa, \& Bažbauers, 2010; Dāce, Pakere, \& Blumberga, 2013) have developed a system dynamic model for analysing the dynamic behaviour of the integrated waste management system of the primary packaging.

The aim of this article is to evaluate cost effectiveness based on cost evaluation of the different complication of the waste pre-treatment equipment variations and based on regenerable waste quantities in Latvia. The tasks:

1. To detect the capacity for the waste pretreatment based on amount of an unsorted waste in the regions.

2. To evaluate costs for the mechanical pretreatment facilities of the municipal solid waste.

The article is a continuation of the study (Arina, Bendere, \& Teibe, 2012; Arina \& Orupe, 2012, 2013; Kalnacs, Arina, \& Murashov, 2013; Teibe, Bendere, Perova, \& Arina, 2012) of the assessment of unsorted municipal waste pre-treatment technologies in Latvia. The results presented in the article are important for development of the waste management system and regeneration in Latvia. Scientific novelty - the mechanical sorting lines for unsorted waste have been evaluated by mass flow analysis, equipment and its operation costs in Latvia, which had not been carried out in Latvia to date.

\section{Materials and Methods}

The mechanical sorting lines for unsorted waste have been evaluated by mass flow analysis and by tools of Microsoft Excel. The materials mass balance of waste separation was established by Equation 1 (Tchobanoglus, Theisen, \& Vigil, 1993).

$$
M_{A}=M_{I}-M_{O}+M_{G}
$$

where $M_{A}$ - rate of accumulation of material within the system boundary;

$M_{I}$ - rate of flow of material into the system boundary; $M_{O}$ - rate of flow of material out the system boundary; $M_{G}$ - rate of generation of waste material within the system boundary. 
Number of residents in waste management regions in Latvia and number of municipalities split by number of residents as at 01.03.2011

\begin{tabular}{|c|c|c|c|c|c|c|c|c|}
\hline \multirow{2}{*}{$\begin{array}{l}\text { Regions of Waste } \\
\text { Management }\end{array}$} & \multicolumn{3}{|c|}{ Population } & \multicolumn{5}{|c|}{ Number of regions split by population } \\
\hline & Town & Rural & Total & $\begin{array}{c}\text { Below } \\
4000\end{array}$ & $\begin{array}{l}4000- \\
10000\end{array}$ & $\begin{array}{l}10000- \\
25000\end{array}$ & $\begin{array}{l}25000- \\
40000\end{array}$ & $\begin{array}{l}\text { Above } \\
50000\end{array}$ \\
\hline Austrumlatgales & 48356 & 45321 & 93677 & 2 & 2 & 1 & 2 & - \\
\hline Dienvidlatgales & 106979 & 80017 & 186996 & 2 & 4 & 3 & - & $1 *$ \\
\hline Liepājas & 105590 & 50543 & 156133 & 5 & 5 & 1 & - & 1 \\
\hline Malienas & 29292 & 45748 & 75040 & 5 & 1 & 3 & - & - \\
\hline Piejūras & 87557 & 53864 & 141421 & 4 & 2 & - & 2 & 1 \\
\hline Pierīgas & 757889 & 135075 & 892964 & 2 & 11 & 6 & 1 & $1 * *$ \\
\hline Ventspils & 51587 & 21721 & 73308 & 1 & - & 2 & 1 & - \\
\hline Vidusdaugavas & 59932 & 49598 & 109530 & 7 & 6 & 2 & - & - \\
\hline Zemgales & 81975 & 92290 & 174265 & 2 & 4 & 3 & - & 1 \\
\hline Ziemel̦vidzemes & 49964 & 117073 & 167037 & 9 & 9 & 4 & - & - \\
\hline
\end{tabular}

*About 90000 people are residing in Daugavpils city.

**About 650000 people reside in the capital city Riga.

Source: Central Statistical Bureau of Latvia

Selection of capacity of mechanical pre-treatment facilities analysed

Firstly, the analysis of WMRs in Latvia was done. Analysis of cost estimates of mechanical sorting lines emphasises the number of residents in regions, which defines amount of waste to be disposed. The Table 1 provides data of density of residents in WMRs in Latvia and split of number of municipalities by number of residents for purposes of establishing necessary capacity of mechanical pretreatment.

Pierīgas WMR has the highest number of municipalities, where the number of residents is from 4 000-10 000 and from $10000-25000$ in each.

The amount of household waste on average is $50-70 \%$ from the total quantities of waste collected in the country. The Table 2 provides theoretically estimated amounts of household waste generated and actually disposed quantities of municipal solid waste by WMRs. The waste amounts were calculated, assuming that one resident produces $250 \mathrm{~kg}$ of waste per year.

The Table 2 shows that the majority of WMRs requires equipment with estimated waste processing capacity of $20 \mathrm{kT} \mathrm{yr}^{-1}$ (Austrumlatgales, Malienas, Ventspils, Vidusdaugavas) and within the range

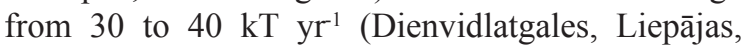
Piejūras, Zemgales and Ziemel̦vidzemes). Only in

Table 1 


\section{Theoretically estimated amount of household waste generated and the amounts of municipal solid waste actually landfilled in AAR}

Table 2

\begin{tabular}{lcc}
\hline $\begin{array}{c}\text { Regions of Waste } \\
\text { management in Latvia }\end{array}$ & $\begin{array}{c}\text { Theoretical generated household waste, } \mathrm{t} \\
(250 \mathrm{~kg} \text { per inhabitant per year) }\end{array}$ & $\begin{array}{c}\text { Landfilled in 2012 (code200301) } \\
\mathrm{t} \mathrm{y}^{-1}\end{array}$ \\
\hline Austrumlatgales & 23419 & 17745 \\
\hline Dienvidlatgales & 46749 & 44692 \\
\hline Liepājas & 39033 & 32351 \\
\hline Malienas & 18760 & $8251^{*}$ \\
\hline Piejūras & 35355 & 25922 \\
\hline Pierīgas & 223241 & 293790 \\
\hline Ventspils & 18327 & 14392 \\
\hline Vidusdaugavas & 27383 & 32582 \\
\hline Zemgales & 43566 & 35961 \\
\hline Ziemel̦vidzemes & $41 \mathbf{7 5 9}$ & $11259^{* *}$ \\
\hline Total & $\mathbf{5 1 7 5 9 3}$ & $\mathbf{5 2 2 ~ 1 4 9}$ \\
\hline
\end{tabular}

* Data of 2011;

**As of 2011 Ziemelvidzemes WMR is actively involved in mechanic pre-sorting of household waste (code: 200301) and preparation for regeneration; therefore, amounts of household waste (HW) disposed in 2012 has significantly decreased, e.g., when comparing the year 2011, when $16462 \mathrm{t}$ of HW were disposed with 2010, when $28002 \mathrm{t}$ of HW were disposed. Sorted waste has been collected from residents in the Ziemelvidzemes WMR already for more than 10 years; therefore, the total quantity of waste to be disposed was lower than in other regions.

Source: Latvian Environment, Geology and Meteorology Centre

- Scenario I - planned annual waste quantities $20 \mathrm{kT}$; planned capacity of equipment $10 \mathrm{th}^{-1}$;

- Scenario II - planned annual waste quantities $40 \mathrm{kT}$; planned capacity of equipment $20 \mathrm{t} \mathrm{h}^{-1}$;

- Scenario III - planned annual waste quantities $160 \mathrm{kT}$; planned capacity of equipment $80 \mathrm{t} \mathrm{h}^{-1}$.

Construction and operational cost data of mechanical pre-treatment

The following formulas are used for cost estimation (2), (3) and (4):

$$
C_{I}=C_{C}+C_{E}+C_{M}
$$

where $C_{I}$ - investments (euro);

$C_{C}$ - capital expenses (construction works) (euro);

$C_{E}$ - cost of equipment (new) (euro);

$C_{M}$ - management or maintenance costs (euro).

The capital expenses are personnel quarters (area $24 \mathrm{~m}^{-2}$ ) (building is provided with infrastructure); operational buildings (modules, $12 \mathrm{~m}^{-2}$ ); sorting area; hangar for waste sorting line; weights with calculation system; electrical and water supply system, lighting, sewerage, waste water purification systems; fence, gates; improvement. The costs include also design and construction field supervision expenses. The comparison does not include price of the land, infrastructure of access roads and the garage is also not planned.

$$
C_{\text {Man. }}=D+M+W+C_{\text {el. fuel }}+O
$$

where $C_{\text {Man. }}$ - management or maintenance costs (euro);

$D$ - depreciation of buildings and equipment (per year) (euro);

$M$ - maintenance cost of buildings and equipment (euro);

$W$ - wages including taxes (euro);

$C_{\text {el.fuel }}$ - electrical energy and fuel costs (euro);

$O$-other expenses (concerned with production 10\%; administration costs $10 \%$ ) (euro).

$$
C=\left(C_{\text {Man. }}+L+T-I\right) / C_{\text {equipm }} \cdot H_{\text {work. }}
$$

where $\quad C \quad-$ costs $\left(\right.$ euro $\mathrm{t}^{-1}$ ) $C_{\text {equipm }}$ - capacity of equipment $\left(\mathrm{t} \mathrm{h}^{-1}\right)$; 
$L$ - costs for landfilling (euro);

$T$ - costs of transportation (euro);

$I$ - income from selling of recyclables;

$H_{\text {work. }}$ - working hours per year.

It was assumed that the mechanical sorting process of unsorted municipal solid waste would produce $\mathrm{RDF}$, recycled raw materials (glass, metal $(\mathrm{Fe})$, aluminium $(\mathrm{Al})$ ), biodegradable waste that can be used for further treatment, and the rest of the waste to be disposed in the landfill (Fig.1). The income from the selling of materials have been defined using the publicly available waste material prices in Latvia: RDF material - 14 euro per t, non-ferrous metals 1100 euro per t, metals -180 euro per t, glass -7 euro per t. Considering current prices for collection of waste at the landfill effective in Latvia (2013), it was assumed that fee for disposal of one ton of municipal solid waste is 28 euro. The transportation costs have been established for a delivery distance of up to $100 \mathrm{~km}$ based on the cost of 1 vehicle-kilometre - 1.16 euro - indicated in the Transport Development Guidelines for 2014-2020 in Latvia.

Management costs are calculated considering prices in Latvia in 2013. The estimated equipment service time is 10 years (Heyer, 2001), whereas that of constructions - 30 years. It is assumed that the construction depreciation ratio is $3.33 \%$, equipment depreciation ratio $-5 \%$, energy price -0.20 euro per $\mathrm{kWh}, 11$ of fuel -1.20 euro . The annual employee salaries have been estimated in three groups: a director - 16000 euro, engineers - 12000 euro, employees 8000 euro. The planned number of working hours is $2000 \mathrm{~h}$ per year.

The average equipment prices have been obtained collecting the offers provided by equipment producers or distributors in different projects and tenders in Latvia, as well as using available sources of literature (Tchobanoglus, Theisen, \& Vigil, 1993; CalRecovery \& PEER Consultants, 1993; Caputo \& Pelagagge, 2002; Eunomia Research \& Consulting, 2002; FCM, 2004; Tsilemou \& Panagiotakopoulos, 2004, 2007). Table 3 shows the ranges of the values of the characteristic capacities and costs for the equipment analyzed in this article.

The equipment has been assembled considering machinery necessary for waste transportation lines, etc. Items included in costs of three scenarios are given below in Table 4.

To assess the costs for different mechanical pretreatment (MP) equipment sets and estimate the amount of the resulting recovered waste material,

Table 3

\section{Characteristics and costs of mechanical pre-treatment equipment and data of literature}

\begin{tabular}{|c|c|c|c|c|}
\hline \multirow[b]{2}{*}{ Position of costs } & \multicolumn{2}{|c|}{ Data from literature (Tsilemou, 2007) } & \multicolumn{2}{|c|}{ Data for article (for planned capacities) } \\
\hline & Capacity $\left(\mathrm{t} \mathrm{h}^{-1}\right)$ & $\begin{array}{c}\text { Purchase Price } \\
(\text { euro })\end{array}$ & Capacity $\left(\mathrm{t} \mathrm{h}^{-1}\right)$ & Purchase Price (euro) \\
\hline Shredders & $0.40-30.00$ & $11700-103600$ & $10-80$ & $270000-950000$ \\
\hline Bag breakers & $3.00-35.20$ & $48900-157500$ & 10 & 150000 \\
\hline Screens & $15.00-191.20$ & $35300-218600$ & $10-80$ & $160000-1200000$ \\
\hline Magnetic separators & $4.30-40.00$ & $7300-54300$ & $10-80$ & $60000-200000$ \\
\hline $\begin{array}{l}\text { Eddy current } \\
\text { separators }\end{array}$ & $1.30-35.00$ & $29300-108600$ & $10-80$ & $120000-240000$ \\
\hline $\begin{array}{l}\text { Manually sorting } \\
\text { cabin }\end{array}$ & - & - & $10-80$ & $120000-180000$ \\
\hline Ballistic separator & - & - & $10-80$ & $220000-750000$ \\
\hline Post-shredder & - & - & $10-80$ & $80000-350000$ \\
\hline Press, baler & 31 & 74000 & $10-80$ & $150000-350000$ \\
\hline Front-loader & - & - & - & 125000 \\
\hline Universal loader & - & - & - & 60000 \\
\hline Containers & - & 300000 & - & $28500-88500$ \\
\hline
\end{tabular}


Mechanical pre-processing equipment sets for three cost scenarios

\begin{tabular}{|c|c|c|c|}
\hline Position of costs & Scenario I $\left(10 \mathrm{t} \mathrm{h}^{-1}\right)$ & Scenario II $\left(20 \mathrm{t} \mathrm{h}^{-1}\right)$ & Scenario III $\left(80 \mathrm{t} \mathrm{h}^{-1}\right)$ \\
\hline Shredder & $\mathrm{x}$ & $\mathrm{x}$ & $\mathrm{x}$ \\
\hline Screener & $\mathrm{x}$ (drum screener) & $\mathrm{x}$ (disc screener) & $\mathrm{x}$ (disc screener) \\
\hline Magnetic separator & $\mathrm{x}$ & $\mathrm{x}$ & $\mathrm{x}$ \\
\hline Eddy current separator & - & $\mathrm{x}$ & $\mathrm{x}$ \\
\hline Manually sorting cabin & $\mathrm{x}$ (with 6 working place) & $\mathrm{x}$ (with 8 working place) & - \\
\hline Ballistic separator & - & $\mathrm{x}$ & $\mathrm{x}$ \\
\hline Post-shredder & $\mathrm{x}$ & $\mathrm{x}$ & $\mathrm{x}$ \\
\hline Press, baler & $\mathrm{x}$ & $\mathrm{x}$ & $\mathrm{x}$ \\
\hline Front-loader & $\mathrm{x}$ & $\mathrm{x}$ & $\mathrm{x}$ \\
\hline Universal loader & $\mathrm{x}$ & $\mathrm{x}$ & $\mathrm{x}$ \\
\hline $\begin{array}{l}\text { Containers } \\
\left(30 \mathrm{~m}^{-3} \text { and } 1.1 \mathrm{~m}^{-3}\right)\end{array}$ & $\mathrm{x}$ & $\mathrm{x}$ & $\mathrm{x}$ \\
\hline
\end{tabular}

Option of mechanical pre-treatment equipment set at capacity of $10 \mathbf{t h}^{-1}$

Table 5

\begin{tabular}{|c|c|c|c|c|}
\hline Pre-treatment equipment & Option 1 & Option 2 & Option 3 & Option 4 \\
\hline Containers & $\mathrm{x}$ & $\mathrm{x}$ & $\mathrm{x}$ & $\mathrm{x}$ \\
\hline Front-loader & $\mathrm{x}$ & $\mathrm{x}$ & $\mathrm{x}$ & $\mathrm{x}$ \\
\hline Universal loader & $\mathrm{x}$ & $\mathrm{x}$ & $\mathrm{x}$ & $\mathrm{x}$ \\
\hline Bag breakers/Openers & $\mathrm{x}$ & - & - & - \\
\hline Shredder & - & $\mathrm{x}$ & $\mathrm{x}$ & $\mathrm{x}$ \\
\hline Manually pre-sorting cabin & $\mathrm{x}$ & - & - & - \\
\hline Disc screens & - & $\mathrm{x}$ & $\mathrm{x}$ & - \\
\hline Rotation drum screens* & $\mathrm{x}$ & - & - & $\mathrm{x}$ \\
\hline Magnets separator & $\mathrm{x}$ & $\mathrm{x}$ & $\mathrm{x}$ & $\mathrm{x}$ \\
\hline Eddy current separators & - & $\mathrm{x}$ & $\mathrm{x}$ & - \\
\hline Manually sorting cabin & $\mathrm{x}$ & - & $\mathrm{x}$ & $\mathrm{x}$ \\
\hline Ballistic separator & - & $\mathrm{x}$ & $\mathrm{x}$ & - \\
\hline Post-shredder & $\mathrm{x}$ & $\mathrm{x}$ & $\mathrm{x}$ & $\mathrm{x}$ \\
\hline Baler, press & $\mathrm{x}$ & $\mathrm{x}$ & $\mathrm{x}$ & $x$ \\
\hline
\end{tabular}

Note. ${ }^{*}$ The size of the sieve of drum screener is $60 \times 60 \mathrm{~mm}$.

Scenario I (the planned waste quantities - $20 \mathrm{kT} \mathrm{yr}^{-1}$; capacity $10 \mathrm{t} \mathrm{h}^{-1}$ ) with constant capital costs analyses the costs of four additional options (Table 5, Fig.1). Material fractions acquired as a result of operation of sorting lines are estimated on the basis of previous studies by the first author regarding the content of waste after its mechanical pre-treatment (Arina \& Orupe, 2012, 2013). 
(Option 1)

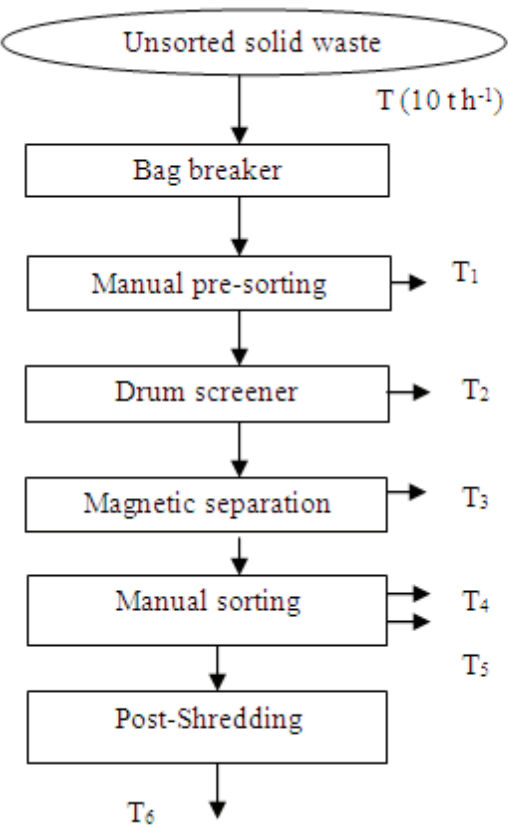

(Option 3)

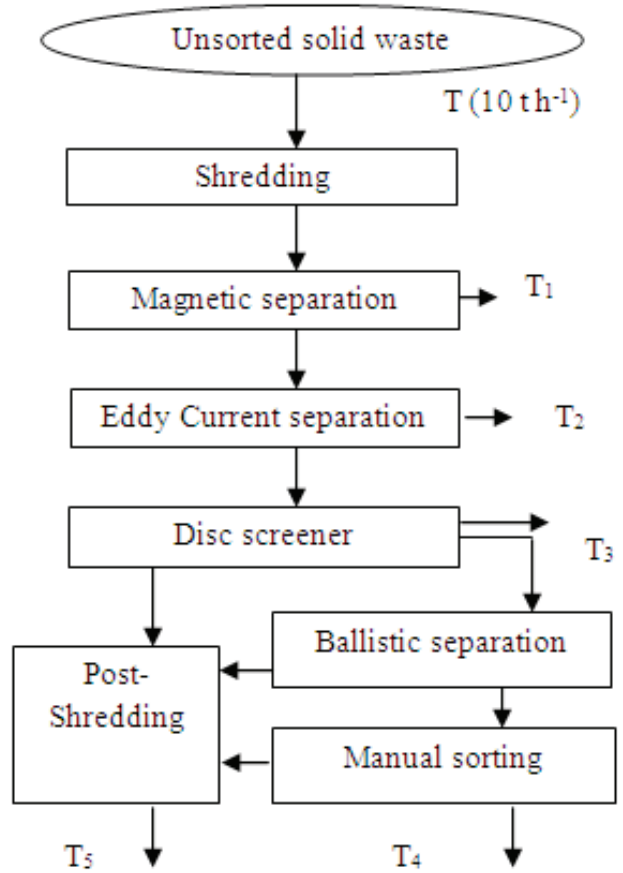

(Option 2)

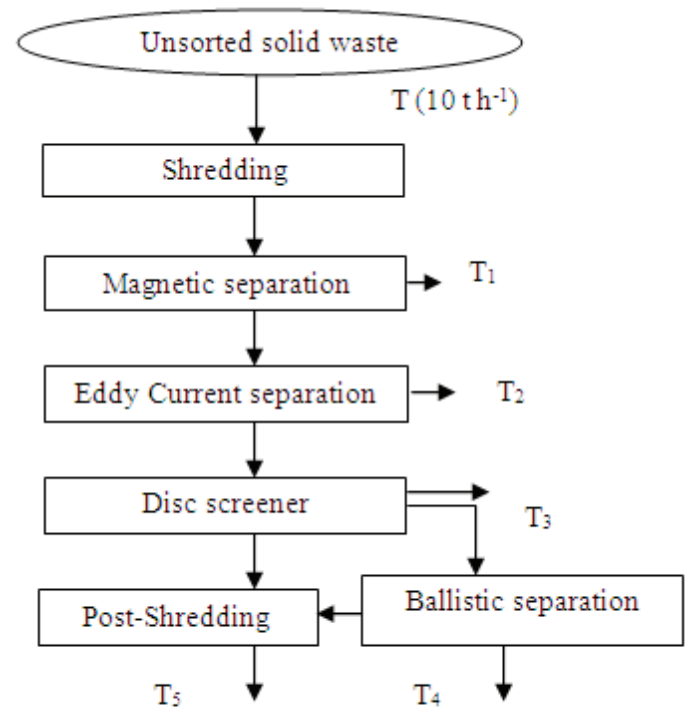

(Option 4)

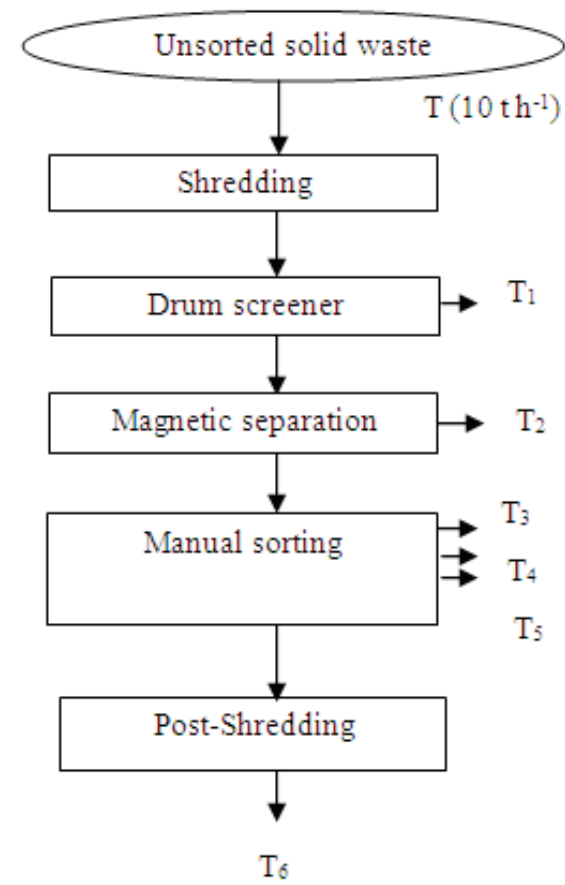

Fig.1. Flow diagrams of pre-treatment facilities for four options.

Note. Option 1: $\mathrm{T}_{1}-$ Glass $\alpha=0.03 ; \mathrm{T}_{2}-$ Fine fraction to Biological treatment $\beta=0.40 ; \mathrm{T}_{3}-$ Ferrous Metals $\gamma=0.02 ; \mathrm{T}_{4}-$ Aluminium $\delta=0.01 ; \mathrm{T}_{5}-$ Residue to Landfill $\varepsilon=0.09 ; \mathrm{T}_{6}-\mathrm{RDF} \zeta=0.45$;

Option 2: $\mathrm{T}_{1}-$ Ferrous Metals $\alpha=0.02 ; \mathrm{T}_{2}-$ Aluminium $\beta=0.01 ; \mathrm{T}_{3}-$ Fine fraction to

Biological treatment $\gamma=0.35 ; \mathrm{T}_{4}-$ Residue to Landfill $\delta=0.40 ; \mathrm{T}_{5}-\mathrm{RDF} \varepsilon=0.22$;

Option 3: $\mathrm{T}_{1}-$ Ferrous Metals $\alpha=0.02 ; \mathrm{T}_{2}-$ Aluminium $\beta=0.01 ; \mathrm{T}_{3}-$ Fine fraction to

Biological treatment $\gamma=0.35 ; \mathrm{T}_{4}-$ Residue to Landfill $\delta=0.16 ; \mathrm{T}_{5}-\mathrm{RDF} \varepsilon=0.46$;

Option 4: $\mathrm{T}_{1}-$ Fine fraction to Biological treatment $\alpha=0.43 ; \mathrm{T}_{2}-$ Ferrous Metals $\beta=0.02$;

$\mathrm{T}_{3}-$ Glass $\gamma=0.01 ; \mathrm{T}_{4}-$ Aluminium $\delta=0.01 ; \mathrm{T}_{5}-$ Residue to Landfill $\varepsilon=0.08 ; \mathrm{T}_{6}-\mathrm{RDF} \zeta=0.45$. 
Option 1 - assumed that of recyclable materials (recovery ratios: glass $\alpha=0.03$, ferrous metals $\gamma=$ 0.02 , aluminium $\delta=0.01$ ) can be acquired, and the fine (incl. biodegradable) fraction (recovery ratio: $\beta=0.40$ ) which, depending on the purity level, can be treated with aerobic and anaerobic methods and used for covering the landfill, and the course fraction (recovery ratio: $\zeta=0.45$ ), which is planned to prepared for regeneration, as well as waste to be disposed in the landfill (recovery ratio: $\varepsilon=0.09$ ). Manual pre-sorting is intended to remove admixtures not suitable for further recycling of biological waste, especially the glass.

Option 2 - assumed that of recyclable materials (recovery ratios: ferrous metals $\alpha=0.02$; aluminium $\beta$ $=0.01$ ) can be acquired, and the fine fraction (recovery ratio: $\gamma=0.35$ ), the course (RDF) fraction (recovery ratio: $\varepsilon=0.22$ ), as well as the medium fraction waste to be disposed in the landfill or incinerated (recovery ratio: $\delta=0.40$ ).

Option 3 - assumed that of recyclable materials (recovery ratios: ferrous metals $\alpha=0.02$; aluminium $\beta$ $=0.01$ ) can be acquired, and the fine fraction (recovery ratio: $\gamma=0.35$ ), the course (RDF) fraction, and the part of manually sorted medium fraction waste, which is planned to be prepared for regeneration (recovery ratio: $\varepsilon=0.46(\varepsilon=0.22+0.24)$ ), as well as medium fraction to be disposed in the landfill (recovery ratio: $\delta=0.16)$.

Option 4 - assumed that of recyclable materials (recovery ratios: ferrous metals $\beta=0.02$; glass $\gamma=$ 0.01 ; aluminium $\delta=0.01$ ) can be acquired, and the fine fraction (recovery ratio: $\alpha=0.43$ ), the course fraction (recovery ratio: $\zeta=0.45$ ), which is planned to be prepared for regeneration, as well as the waste to be disposed in the landfill (recovery ratio: $\varepsilon=0.08$ ).

Paper and plastics recyclable materials can also be separated by applying mechanical sorting technologies; however, high quality materials can only be obtained from source separated paper and plastic waste. Therefore, in the estimates it is considered that these materials are intended for RDF production.

\section{Results}

The MP costs of municipal solid waste (MSW) in the three scenarios of mechanical sorting lines for MSW with the equipment capacities of $10 \mathrm{t} \mathrm{h}^{-1}, 20 \mathrm{t}$ $\mathrm{h}^{-1}$ and $80 \mathrm{t} \mathrm{h}^{-1}$ are 32 euro per t, 24 euro per $\mathrm{t}$ and 15 euro per t, respectively. The equipment costs are $56 \%$ of the capital investments in Scenario I and 59\% in Scenarios II and III (Fig. 2).

The economically most profitable solution is Scenario III, which - considering the potential waste amounts - can be implemented only in the Pierīga waste management region. With the increase in the cost of landfilling, Scenario I also becomes profitable, which - considering the available quantity - is suitable for a large part of waste management regions, assuming that separate waste collection will be developed.

Salaries of employees in Scenario I are $17 \%$, in Scenario II $-15 \%$ and in Scenario III $-7 \%$ from management costs, while the electrical energy and fuel costs are $40 \%, 36 \%$ and $41 \%$, respectively (Fig. 3).

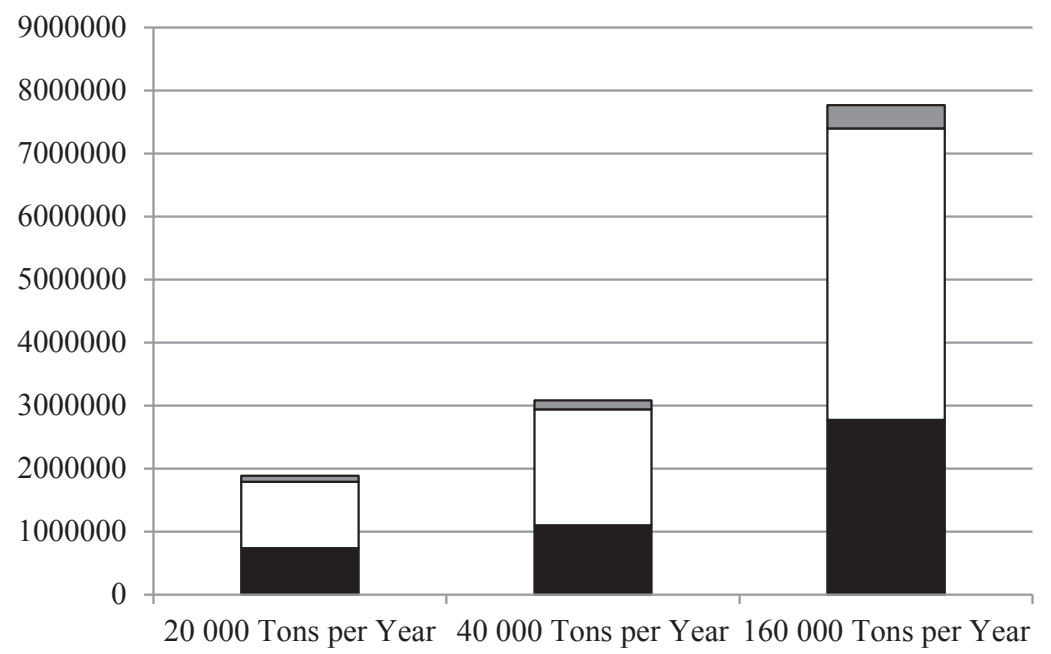

Fig.2. The comparison of investments (euro) for three scenarios of mechanical pre-treatment of municipal solid waste.

- Capital costs; $\square-$ Costs of equipment; $\square-$ Costs of projecting, organization of construction. 


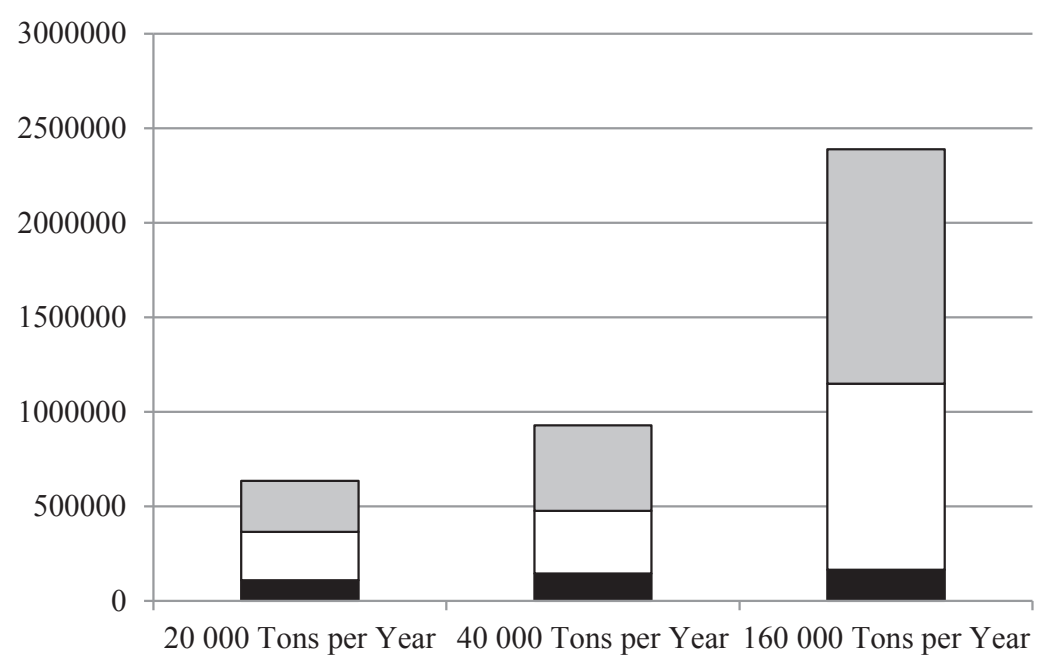

Fig.3. The comparison of overhead expenses (euro) for three scenarios of mechanical pre-treatment of municipal solid waste.

- - Costs of personnel wage; $\square-$ Costs of energy and fuel; $\square-$ Other costs of management).

Table 6

Options of sets of mechanical pre-treatment technologies at capacity of $10 \mathrm{th}^{-1}$ and costs for 1 ton of waste

\begin{tabular}{lcccc}
\hline \multicolumn{1}{c}{ Costs } & Option 1 & Option 2 & Option 3 & Option 4 \\
\hline Costs, euro $^{-1}$ & 36 & 34 & 39 & 32 \\
\hline Costs, incl. dispose in the landfill, euro $\mathrm{t}^{-1}$ & 38 & 45 & 43 & 34 \\
\hline $\begin{array}{l}\text { Costs, incl. income from realization and costs } \\
\text { of transportation till } 100 \mathrm{~km}_{\text {euro }} \mathrm{t}^{-1}\end{array}$ & 23 & 31 & 28 & 19 \\
\hline $\begin{array}{l}\text { Costs, incl. income from realization and costs } \\
\text { of transportation till } 250 \mathrm{~km}_{\text {, euro } \mathrm{t}^{-1}}\end{array}$ & 32 & 41 & 35 & 26 \\
\hline
\end{tabular}

Table 6 shows costs of four options mechanical pre-treatment technologies set versions for 1 ton of waste for equipment capacity of $10 \mathrm{th}^{-1}$.

While the prices of equipment sets for Options 1 and 4 are equal, pre-treatment costs for 1 tonne of waste for Option 4 are lower, as it requires smaller labour force of manual work. The costs of Option 4 with a drum screener and manual sorting are the lowest; however, it must be taken into account that the proportion of the fine fraction (incl. biodegradable waste) after the use of a rotating drum screener is larger and contains a higher proportion of admixtures than after the disc screener.

For all four options, the income from selling the recovered materials exceeds the transportation costs up to the distance of $250 \mathrm{~km}$.
The analysis of the results of the above options shows that in Option 1, as compared to Option 4, more material unsuitable for RDF generation can be sorted manually, thereby improving RDF quality although slightly increasing the amount of waste to be landfilled. While sorting lines in combination with manual sorting are more efficient in terms of costs, as higher quality material can be sorted, manual sorting of unsorted waste is considered to be work dangerous to health, which is why manual sorting is mainly used for sorting separated waste at source (Tchobanoglus, Theisen, \& Vigil, 1993).

\section{Discussion}

Prices of equipment fluctuate and depend on equipment specification, quantity, geographic 
location, transportation costs, discounts offered by sellers of machinery, etc. factors. It also has to be considered that every procurement tender contains certain provisions not allowing detailed price comparison, but rather just demonstrating overall kind of expenses.

According to Thiel (Thiel \& Thomé-Kozmiensky, 2009), the waste disposal costs with the set of mechanical - biological waste treatment plants and waste incineration plants are equal in Germany namely 100 euro per t. An average cost for disposal of waste in landfill in Latvia is 28 euro per $t$ in prices of 2013, however, it is planned that the disposal price will be gradually increased.

According to data of the European Commission's research of 2003 (European Commission, 2003), the costs for RDF production from municipal solid waste in Belgium were 50-75 euro per ton.

Construction costs can be within the range of $40-70 \%$ from total investment, which in study scenarios, including designing are: in the Scenario I $-44 \%$, in Scenarios II and III - 40\% from total investment.

According to Heyer et al. (Heyer, Hupe, \& Stegmann, 2001) referring to studies of Turk, Fricke, Hake the theoretical example of assessment of mechanical pre-treatment costs (prices of 1997) for a set of machinery intended for waste handling capacity of $30 \mathrm{kT} \mathrm{yr}^{-1}$ depending on purposes of processing:

- Containers and pre-shredder - 24 euro per t;

- Containers, pre-shredder, magnetic separation, sieving $(100 \mathrm{~mm})-27$ euro per $\mathrm{t}$;

- Containers, pre-shredder, magnetic separation, sieving $(100 \mathrm{~mm})$, post-shredder, sieving $(40 \mathrm{~mm})$ - 33 euro per t;

The example from literature sources has been compared against costs acquired within this study considering type of equipment. In comparison of expenses it must be considered that current prices of equipment are higher than those in 1997; however, studied prices in Latvia are considerably lower even without application of levelling coefficients. This could be explained by higher price for services in Germany.

According to Pubule et al. (Pubule, Kamenders, Valtere, \& Blumberga, 2014) the minimal operational costs and capital costs for Baltic States are as follows:

- For anaerobic digestion of separately collected biowaste 28.00 euro and 376 euro per ton;

- For composting of separately collected biowaste 8.00 euro and 124.5 euro per ton of waste;

- For MBT with anaerobic digestion 28.00 euro and 372 euro per ton of waste;

- For MBT with composting 14.00 euro and 176 euro per ton of waste;
- For waste incineration with energy recovery 20.00 euro and 651 euro per ton of waste;

- For waste incineration without energy recovery 22.00 euro and 631 euro per ton of waste;

- For landfilling of biowaste 5.00 euro and 119 euro per ton of waste.

Data of estimation are not directly comparable as there are not costs for mechanical pre-treatment of the unsorted municipal solid waste in the literature.

When analysing economic benefits of mechanical biological pre-treatment of waste, unsorted household waste is basically divided into material groups: valuable materials, organic materials, light fractions, heavy fraction and residual materials. The purpose of mechanical pre-treatment is to separate valuable materials, which could be used and to separate currently not applicable materials, which shall be disposed in the landfill. According to descriptions of technology in the EU countries, available in sources of literature (Soyez \& Plickert, 2001), when the purpose of technology is separation of fuel from waste, the fine fraction is planned to be further hygienised after the sieve with biological pre-treatment technologies and then once more sieved through finer material in order to separate sorts of waste suitable for fuel production. Thus, about $75-80 \%$ of materials can be reclaimed for production of fuel.

Sales of reclaimed materials such as aluminium in the future could decrease, when the planned deposit system for aluminium packaging will be introduced in Latvia (planned in 2013) (Brizga, Dimante, \& Atstāja, 2012; Dāce, Bērziņa, \& Bažbauers, 2010; Dāce, Pakere, \& Blumberga, 2013).

According to data provided in sources of literature, quality compost can be obtained from source sorted biodegradable waste, not mechanically biologically pre-treated unsorted waste. Therefore, the current waste management system in Latvia, when source sorting of biodegradable catering waste is not developed, the lines for mechanical pre-treatment of unsorted municipal solid waste are better used in landfill.

\section{Conclusions}

1. Lower costs of mechanical pre-treatment of one ton of waste correspond to larger quantities of waste and processing capacity as shown by evaluation of the mechanical pre-treatment of the unsorted municipal solid waste. The costs of mechanical pre-treatment scenarios with the equipment capacities of $10 \mathrm{t} \mathrm{h}^{-1}, 20 \mathrm{t} \mathrm{h}^{-1}$ and 80 $\mathrm{t} \mathrm{h}^{-1}$ are 32 euro per $\mathrm{t} ; 23$ euro per $\mathrm{t}$ and 15 euro per $\mathrm{t}$, respectively.

2. The mechanical pre-treatment equipment for unsorted waste is economically little effective, 
if fine (biologically degradable) fraction cannot be used.

3. The cost effective choice for mechanical pretreatment facility of $10 \mathrm{th}^{-1}$ is 32 euro per $\mathrm{t}$, using rotating drum screener with the following manual sorting. The separation of the fine fraction from unsorted municipal solid waste can be ensured by a drum screener, which is about $33 \%$ cheaper than a disc screener.

4. Feasibility study shall be developed for each waste management region separately, since there are too many local factors affecting costs.

\section{References}

1. Arina, D., Bendere, R., \& Teibe, I. (2012). Pre-treatment processes of waste reducing the disposed amount of organic waste and greenhouse gas emission. In: The ISWA World Solid Waste Congress 2012, 17-19 September 2012. Florence, Italy, No. 517, 1-9. Proceedings. Florence: International Solid Waste Association.

2. Arina, D., \& Orupe, A. (2012). Characteristics of Mechanically Sorted Municipal Wastes and Their Suitability for Production of Refuse Derived Fuel. Environmental and Climate Technologies. 1(Jun), 18-23.

3. Arina, D., \& Orupe, A. (2013). Comparison of municipal solid waste characteristics after separation by star and drum screen systems. In: International Scientific Conference Civil Engineering '13, 16-17 May 2013 (28), 318322. Jelgava, Latvia: Latvia University of Agriculture.

4. Brizga, J., Dimante, D., \& Atstāja, D. (2012). Economic Assessment of Introduction of Deposit System in Latvia Depozìta sistēmas ieviešanas ekonomiskais novērtējums Latvijā. Association "Green Liberty". Riga: Association “Green Liberty”. 1-47. Retrieved 18 May, 2014, from: http://www.zb-zeme.lv.

5. CalRecovery \& PEER Consultants (1993). Material Recovery Facility Design Manual, C.K. Smoley - CRC Press, Boca Raton, Florida, 1-176.

6. Caputo, A.C., \& Pelagagge, P.M. (2002). RDF production plants: I Design and costs. Applied Thermal Engineering. 22 (4), 423-437.

7. Dāce, E., Bērziņa, A., \& Bažbauers, G. (2010). Analysis of Waste Sorting Population in Latvia by Using System Dynamics Modeling. In: Proceedings of $7^{\text {th }}$ International Conference on Natural Sciences and Technologies for Waste and Wastewater Treatment, Remediation, Emissions Related to Climate, Environmental and Economic Effects, Sweden, Kalmar:
Linnaeus University, November 22-24, 2010, 485-494.

8. Dāce, E., Pakere, I., \& Blumberga, D. (2013). An Evaluation of Economic Aspects of the Deposit-Refund System for Packaging in Latvia. Management of Environmental Quality; An International Journal. 24 (3), 311-329.

9. Economic Analysis of Options for Managing Biodegradable Municipal Waste. (2002). Final Report to the European Commission, Copenhagen. Eunomia Research \& Consulting. 1-202. Retrieved November 1, 2013, from: http://europa.eu.int.

10. European Parliament (2008). Directive 2008/98/ EC of the European Parliament and of the Council of 19 November 2008 on Waste and Repealing certain Directives. Official Journal L 312/3, 22/11/2008, 0003-0030.

11. Heyer, K.-U., Hupe, K., \& Stegmann, R. (2001). Mechanical-biological pretreatment and energetic recovery of rdf fractions in Germany: experiences and costs. In: Kuudes Jätehuollon Tutkimusseminaari 2001 - 6th Finnish research seminar on solid waste management, 2001 (102-116). Helsinki, Finland: University of Technology Laboratory of Environmental Engineering.

12. Kalnacs, J., Arina, D. \& Murashov, A. (2013). Content and Properties of Mechanically Sorted Municipal Wastes and Their Suitability for Production of Alternative Fuel. Renewable Energy \& Power Quality Journal (RE\&PQJ) 11 (March), paper 8, No. 525, 1-4. Retrieved August 6, 2013, from: http://www.icrepq.com.

13. Preparation of Documentation for Municipal Waste Incineration. Pre-feasibility Study. (2007). Kaunas University of Technology (KUT) (No.2005/24/A/P/LT), 1-81.

14. Pubule, J., Kamenders, A., Valtere, S., \& Blumberga, D. (2014). Cleaner production in biowaste management. Agronomy Research. 12(2), 575-588. ISSN: 1406-894X.

15. Refuse Derived Fuel, Current Practice and Perspectives. (2003). Final report (B43040/2000/306517/MAR/E3). European Commission, 1-229.

16. Rimaityte, I., Denafas, G., Martuzevicius, D. \& Kavaliauskas, A. (2010). Energy and Environmental Indicators of Municipal Solid Waste Incineration: toward Selection of an Optimal Waste Management System, Polish J. of Environ. Stud. 19 (5), 989-998. Retrieved August 6, 2013, from: http://www.pjoes.com.

17. Ritzkowski, M., Heerenklage J., \& Stegmann R. (2006). An overview on techniques 
and regulations of mechanical-biological pre-treatment of Municipal Solid Waste. Environmental Biotechnology. 2, 57-68.

18. Screening of Waste Management Performance of EU Member States. (2012). European Commission. 1-49. Retrieved November 1, 2013, from: http://ec.europa.eu/environment/ waste/studies/pdf/Screening_report.pdf.

19. Soyez, K., \& Plickert, S. (2001). MechanicalBiological Pre-Treatment of Waste - State of the Art and Potentials of Biotechnology, 1-17, Retrieved December 8, 2012, from: http://www. gts-oekotech.de

20. Solid waste as a resource, Rewiew of waste Technologie. (2004). Federation of Canadian Municipalities (FCM). 1-140. Retrieved May 13, 2013, from: http://www.fcm.ca.

21. Stegmann, R. (2005). Mechanical biological pretreatment of municipal solid waste. In: Tenth International Waste Management and Landfill Symposium, 3-7 October 2005 (1-11). Sardinia, Cagliari, Italy: CISA.

22. Tchobanoglous, G., Theisen, H., \& Vigil, S.A. (1993). Integrated Solid Waste Management: Engineering principles and management issues. USA: McGraw-Hill, Inc. 1-978.

23. Teibe I., Bendere, R., Perova, L., \& Arina, D. (2012). Mathematical models for regional solid waste management development. In: 18th International Conference Linnaeus ECOTECH 2012, November 26-28, 2012 (622-633). Sweden, Kalmar. Proceedings.

24. Thiel, S., \& Thomé-Kozmiensky, J.K. (2009). Mechanical-Biological Pre-treatment of Waste - Hope and Reality, 1-16. Retrieved May 13, 2013, from: http://www.iswa.org.

25. Tsilemou, K., \& Panagiotakopoulos, D. (2004). Estimating Costs for Solid Waste Treatment Facilities. 1-12. In: ISWA World Environmental Congress and Exhibition, 17-21 October 2004 (, Rome, Italy. Proceedings.

26. Tsilemou, K., \& Panagiotakopoulos, D. (2007). Economic Assessment of Mechanical-Biological Treatment Facilities. Aplinkos tyrimai, inžinerija ir vadyba (Environmental Research, Engineering and Management). 1(39), 55-63. ISSN 13921649.

27. National Inventory Submissions 2012. (2012). United Nations Framework Contention on Climate Change (UNFCCC). 1-13. Retrieved May 13, 2013, from: http://unfccc.int/national_ reports/annex_i_ghg_inventories/national_ inventories_submissions/items/6598.php.

\section{Acknowledgements}

Acknowledgement to the European Social Fund (ESF) agreement No: 2009/0180/1DP/1.1.2.1.2/09/IPIA/ VIAA/017 for the doctoral research grant award to the first author and to Dr.sc.ing. Ritvars Sudärs as a scientific supervisor of corresponding doctoral thesis - Pre-treatment and Energy Recovery of Municipal Solid Waste. 